Article

\title{
Synthesis and Characterization of FITC Labelled Ruthenium Dendrimer as a Prospective Anticancer Drug
}

\author{
Sylwia Michlewska 1,2 (D), Małgorzata Kubczak ${ }^{2}$, Marta Maroto-Díaz ${ }^{3,4}$, \\ Natalia Sanz del Olmo ${ }^{3,4}$, Paula Ortega ${ }^{3,4}$, Dzmitry Shcharbin ${ }^{5} \mathbb{D}$, Rafael Gomez Ramirez ${ }^{3,4,6}$, \\ Francisco Javier de la Mata ${ }^{3,4,6}$, Maksim Ionov ${ }^{2, *(D)}$ and Maria Bryszewska ${ }^{2}$ \\ 1 Laboratory of Microscopic Imaging and Specialized Biological Techniques, Faculty of Biology and \\ Environmental Protection, University of Lodz, Banacha12/16, 90-237 Lodz, Poland \\ 2 Department of General Biophysics, Faculty of Biology and Environmental Protection, University of Lodz, \\ Pomorska 141/143, 90-236 Lodz, Poland \\ 3 Networking Research Center on Bioengineering, Biomaterials \& Nanomedicine (CIBER-BBN), Monforte de \\ Lemos 3-5, Pabellon' 11, Planta, 028029 Madrid, Spain \\ 4 Departamento Química Orgánica y Química Inorganica, Universidad de Alcalá, Instituto de Investigación \\ Química “Andrés M. del Río" (IQAR), UAH, 28871 Alcalá de Henares, Spain \\ 5 Institute of Biophysics and Cell Engineering of NASB, Akademicheskaja 27, 220072 Minsk, Belarus \\ 6 Instituto Ramon y Cajal de Investigacion Sanitaria, IRYCIS, Colmenar Viejo Road, Km 9, 100, 28034 Madrid, \\ Spain \\ * Correspondence: maksim.ionov@biol.uni.lodz.pl; Tel.: +48-426354380
}

Received: 22 July 2019; Accepted: 21 August 2019; Published: 25 August 2019

\begin{abstract}
Metallodendrimers-dendrimers with included metals-are widely investigated as biocompatible equivalents to metal nanoparticles. Applications can be expected in the fields of catalysis, as chemical sensors in molecular recognition and as anticancer drugs. Metallodendrimers can also mimic certain biomolecules, for example, haemoprotein in the case of using a dendrimer with a porphyrin core. In previous papers, we showed the promising anticancer effects of carbosilane ruthenium dendrimers. The present paper is devoted to studying biocompatibility and the cytotoxic effect on normal and cancer cells of carbosilane ruthenium dendrimers labelled with fluorescent probe fluorescein isothiocyanate (FITC). The addition of fluorescent probe allowed tracking the metallodendrimer in both normal and cancer cells. It was found that carbosilane ruthenium dendrimer labelled with FITC in concentration up to $10 \mu \mathrm{mol} / \mathrm{L}$ was more cytotoxic for cancer cells than for normal cells. Thus, FITC labelled carbosilane ruthenium dendrimer is a good candidate for diagnostic imaging and studying anticancer effects of metallodendrimers in cancer therapy.
\end{abstract}

Keywords: ruthenium dendrimer; FITC labelled dendrimer; anticancer therapeutic agent; controlled polymer carrier

\section{Introduction}

Cancers are the second main cause of mortality in the world after cardiovascular diseases. The wide heterogeneity of cancers and their metastasising pose huge challenges for discovering new methods of treatment [1]. Despite the development of many anticancer agents, high mortality often results from the poor, non-selective delivery systems unable to target only cancer cells. Metal compounds, for example cisplatin, are well known anticancer agents due to their mechanism of action [2,3]. Unfortunately, they are highly cytotoxic, not only for tumour tissues, but for the whole body. Cisplatin is widely used 
in cancer therapy, but its anticancer activity is limited by its adverse side effects (anaemia, diarrhoea, nephrotoxicity and neurotoxicity). Many cancers have become resistant to treatment with this metal [2].

Now, novel metal compounds (zinc, copper, and ruthenium) are under investigation as potential anticancer drugs [2-4]. It was demonstrated that ruthenium exhibited anti-tumour activity with limited side effects towards normal cells [5]. Thus, ruthenium-based drugs may be an alternative to more toxic platinum agents. Ruthenium can have II, III or IV oxidation states; the oxidation state III does not damage cells. Due to the low $\mathrm{pH}$ and high glutathione level characteristic of cancer cells, ruthenium can be reduced to II oxidative state, which is highly toxic towards cells [5]. The detailed analysis of metallodrugs has shown that complexes containing these metal ions are already in clinical use or have advanced to clinical trials as anticancer agents. The "multitargeted" complexes described herein not only target DNA but also contain vectors to enable them to target cancer cells selectively and/or moieties that target enzymes, peptides, and intracellular proteins [6,7]. The anticancer activities of ruthenium include inhibition of DNA and RNA synthesis, which leads to apoptosis. However, the biggest impediment for use of ruthenium compounds is their poor solubility in water [8]. Therefore, creating ruthenium compounds that are soluble in water and can transfect cancer cells is important [9]. Currently, the attention of scientists is focused on controlled delivery of cancer therapies or on targeted diagnostic imaging $[10,11]$. The use of nanotechnology seems to be very promising. Targeted use of a drug, with the possibility of imaging the process of its application, will increase therapeutic efficacy and further minimise side effects [12]. For many years, nanoparticles, especially dendrimers, have been under investigation as systems for delivery of drugs to cancer cells. Dendrimers are very convenient subjects to study [13]: they are synthesised in a controlled manner; their molecular weight, surface charge and size are well defined; and they consist of a core and polymer branches. The ends of polymer branches can be modified in different ways. Due to these features, they are promising agents to be used in many scientific fields, especially in gene and drug delivery systems [14]. Their low immunogenic activity and cytotoxicity make them attractive carriers for poorly-soluble drugs or nucleic acids. Gene therapy seems a very promising method to overcome many cancers but finding the most effective gene delivery system is still a challenge. The hydrophobic nature and stability of carbosilane ruthenium dendrimers may facilitate their interaction with biological membranes. Additionally, it is known that they can create complexes with nucleic acids [14-16]. Big progress in metallodendrimers was achieved at the University of Cape Town [17]. They developed a wide range of Ru-based metallodendrimers and studied their effects in vitro against A2780 and A2780cisR human ovarian cancer lines, the SISO human cervix cancer line, the LCLC-103H human lung cancer line, and the 5637 human bladder cancer line. Nine of the twelve compounds slowed the growth of the ovarian cancer cell lines by more than $50 \%$ at equi-iron concentrations of $5 \mu \mathrm{mol} / \mathrm{L}$ [17]. Except dendrimers, other nanoformulations are used to improve the delivery of ruthenium into cancer cells. Heffeter et al. [18] presented a new nanoparticle formulation based on polymer-based micelles loaded with the anticancer lead ruthenium compound KP1019. Nanoprepared KP1019 was characterised by enhanced stability in aqueous solutions. Moreover, the nanoparticle formulation facilitated cellular accumulation of KP1019 (determined by Inductively coupled plasma mass spectrometry (ICP-MS) measurements) resulting in significantly lowered $\mathrm{IC}_{50}$ values [18]. The KP1019 poly(lactic acid) nanoparticles of KP1019 with two different surfactants (Pluronic F68 and Tween 80) were prepared [19] and cytotoxicity measurements comparing different aged Tween 80 nanoparticles revealed that the colour change from brown to green was associated with an up to 20 fold increased activity compared to "free" KP1019 [19]. Hollow mesoporous ruthenium nanoparticles conjugating bispecific antibody for targeted anti-colorectal cancer response of combination therapy were proposed by Xu et al. [20]. Systematic in vivo studies clearly demonstrated the high tumour targeting and anticancer activity in heterotopic colorectal tumour model via combined photothermal and immune therapy [20]. As for imaging, Dou et al. [21] proposed a ruthenium-complex-functionalized two-photon-excited red fluorescence silicon nanoparticle composite based on fluorescence resonance energy transfer under mild experimental conditions. Fluorescence imaging tests in zebrafish and nude mice indicated that such nanoparticle 
could act as a new kind of fluorescence probe for fluorescence imaging in vivo. The present paper is devoted to studying biocompatibility and cytotoxic effect on normal and cancer cells of carbosilane ruthenium dendrimer labelled with fluorescent probe fluorescein isothiocyanate (FITC). The addition of a fluorescent probe allows tracking the metallodendrimer in normal and cancer cells.

\section{Materials and Methods}

\subsection{Ruthenium-Terminated Carbosilane Dendrimer with FITC (CRD13-FITC)}

The new heterofunctional ruthenium-terminated carbosilane dendrimer with FITC (CRD13-FITC), G1- $\left\{[[\mathrm{NCPh}(\mathrm{o}-\mathrm{N}) \mathrm{Ru}(\eta 6-\mathrm{p} \text {-cymene }) \mathrm{Cl}] \mathrm{Cl}]_{3}[\mathrm{FITC}]\right\}$ (3), was prepared as described below and characterized through Nuclear Magnetic Resonance, Elemental Analysis, UV-Vis and IR spectroscopy (see the Supplementary Materials for structural characterization).

G1-[(NCPh $\left.(\mathrm{o}-\mathrm{N}))_{3} \mathrm{NH}_{2}\right]$ (1). Carbosilane dendrimer G1-[ $\left.\mathrm{NH}_{2}\right]_{4}(313.1 \mathrm{mg} 0.47 \mathrm{mmol})$ was dissolved in THF, and 2-pyridinecarboxaldehyde (152.1 mg, $1.42 \mathrm{mmol}$ ) was added. The mixture was stirred in an inert atmosphere at room temperature in anhydrous $\mathrm{MgSO}_{4}$ for $12 \mathrm{~h}$. The solution was filtered and the solvent evaporated to isolate dendrimer 1 as an orange oil $(354.1 \mathrm{mg}, 80 \%)$. This reaction was controlled by ${ }^{1} \mathrm{H}-\mathrm{NMR}$. The corresponding aldehyde was added in portions. By using NMR, the percentage of amino groups that had reacted was calculated; thus, the reaction could be stopped when there were $25 \%$ unreacted amino groups. Finally, we carried out the experiment of elemental analysis to corroborate the purity of the final product.

G1-[(NCPh(o-N)Ru(n6-p-cymene) $\left.\left.\mathrm{Cl}_{2}\right)_{3} \mathrm{NH}_{2}\right]$ (2). Compound 1 (96.2 mg, $0.104 \mathrm{mmol}$ ) was dissolved in $\mathrm{EtOH}$ and added dropwise at $0{ }^{\circ} \mathrm{C}$ to a solution of $\left[\mathrm{Ru}(\eta 6-\mathrm{p}-\mathrm{cymene}) \mathrm{Cl}_{2}\right]_{2}(95.5 \mathrm{mg}$, $0.156 \mathrm{mmol}$ ) in $\mathrm{EtOH}$. The mixture was stirred at r.t. for $12 \mathrm{~h}$. Subsequently, the solvent was evaporated to isolate compound 2 as a water-soluble red solid $(115.1 \mathrm{mg}, 60 \%)$.

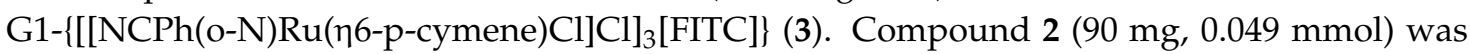
dissolved in EtOH and FITC (1.0 eq.) was added. The mixture was stirred under dark and inert atmosphere at $55{ }^{\circ} \mathrm{C}$ for $12 \mathrm{~h}$. Subsequently, the solvent was evaporated and the product was washed with water and dialyzed with a membrane with molecular weight cut-off 100-500 Da for $72 \mathrm{~h}$. Compound 3, referred to here as CDR13-FITC, was isolated as a brown solid (65.8 mg, 60\%).

\subsection{Zeta Potential}

Zeta potential of CRD13-FITC was measured using a Photon Correlation spectrometer Zetasizer Nano ZS Malvern Instruments (Malvern Instruments Limited, Worcestershire, UK). Measurement of $20 \mu \mathrm{mol} / \mathrm{L}$ dendrimer was made in distilled water at $25^{\circ} \mathrm{C}$. The values were calculated from the Helmholtz-Smoluchowski equation. From 9 to 12 measurements were collected and averaged for each sample.

\subsection{Measurement of Particle Size}

The size of CRD13-FITC dendrimer at $20 \mu \mathrm{mol} / \mathrm{L}$ was measured using Malvern Zetasizer Nano-ZS (Malvern Instruments Limited, Worcestershire, UK) spectrometer by dynamic light-scattering technique. The wavelength was set to $633 \mathrm{~nm}$, the detection angle to $90^{\circ}$, and the refraction factor to 1.33 . All samples were prepared in distilled water. Nanoparticle size was measured from the average of $7 \times 3$ cycles at $25^{\circ} \mathrm{C}$. The data were analysed using Malvern software.

\subsection{Transmission Electron Microscopy}

To examine dendrimer morphology, TEM was used. Ten microliters of dendrimer solution at $1 \mathrm{mmol} / \mathrm{L}$ were placed on 200-mesh carbon-coated copper grids. The sample was stained with saturated uranyl acetate for $20 \mathrm{~min}$, washed in demineralised water and dried at room temperature. Images were obtained using a JEOL1010 transmission electron microscope (JEOL, Tokyo, Japan). 


\subsection{Haemotoxicity}

Blood obtained from healthy donors was purchased from Central Blood Bank, Lodz, Poland. It was centrifuged and washed twice with PBS at pH 7.4. Erythrocytes were used immediately after isolation. From 0.5 to $50 \mu \mathrm{mol} / \mathrm{L}$ of CRD13 FITC dendrimer was added to the red blood samples (haematocrit $2 \%$ ) and incubated for $24 \mathrm{~h}$ at $37^{\circ} \mathrm{C}$. Haemolysis percentage was calculated as follows:

$$
\mathrm{H}(\%)=\left(\mathrm{A}_{\mathrm{pb}} 540 \mathrm{~nm} / \mathrm{A}_{\text {water }} 540 \mathrm{~nm}\right) \times 100 \% .
$$

$\mathrm{H}(\%)$ is the percentage of haemolysis, $\mathrm{A}_{\mathrm{pb}} 540 \mathrm{~nm}$ is the absorbance of the erythrocytes incubated with CRD13-FITC, and $A_{\text {water }} 540 \mathrm{~nm}$ is the absorbance of erythrocytes incubated with water $(100 \%$ haemolysis, positive control).

\subsection{Fluorescence Anisotropy}

Human erythrocyte membranes were used to analyse changes of fluorescence anisotropy. Red blood cells were haemolysed in $30 \mathrm{mM}$ Na-phosphate buffer at $\mathrm{pH} 7.4$ and at $4{ }^{\circ} \mathrm{C}$ before being centrifuged ( $15 \mathrm{~min}, 15,000 \times g$ at $4{ }^{\circ} \mathrm{C}$ ). Membranes were separated from haemoglobin and washed several times with Na-phosphate buffer diluted in water. Protein concentration was estimated by the Lowry method [22]. The erythrocyte membranes were frozen and used within two weeks.

Fluorescence anisotropy of two fluorescent markers, 1,6-diphenyl-1,3,5-hexatriene (DPH) and 1-(4-(trimethyloamino)phenyl)-6-phenylhexa-1,3,5-triene (TMA-DPH), was measured in rising concentrations of CRD13-FITC.

LS-50B (Perkin Elmer, UK) spectrofluorimeter was used to monitor the fluidity of membranes. Excitation and emission wavelengths were $348 \mathrm{~nm}$ and $426 \mathrm{~nm}$ for DPH and $358 \mathrm{~nm}$ and $428 \mathrm{~nm}$ for TMA-DPH, respectively. The slit width of the excitation monochromator was $2.5 \mathrm{~nm}$ and that for emission monochromator was $6 \mathrm{~nm}$ for all samples. The measurements were performed at $37^{\circ} \mathrm{C}$. Membranes were dissolved in Na-phosphate buffer, $\mathrm{pH}$ 7.4. the fluorescent probes were added at $25 \mu \mathrm{g}$ proteins $/ \mathrm{mL}$. The concentration of both fluorescent probes was $1 \mu \mathrm{mol} / \mathrm{L}$. After 10 min incubation, fluorescence anisotropy was measured. CRD13-FITC was dissolved in water and added to each sample to reach the appropriate concentration. Fluorescence anisotropy was calculated using Perkin Elmer software from Jablonski's equation:

$$
\mathrm{r}=\left(\mathrm{I}_{\mathrm{VV}}-\mathrm{GI}_{\mathrm{VH}}\right) /\left(\mathrm{I}_{\mathrm{VV}}+\mathrm{GI}_{\mathrm{VH}}\right)
$$

where $\mathrm{r}$ is fluorescence anisotropy, and $\mathrm{I}_{\mathrm{VV}}$ and $\mathrm{I}_{\mathrm{VH}}$ are the vertical and horizontal fluorescence intensities, respectively, to the vertical polarisation of the excitation light beam. $\mathrm{G}=\mathrm{I}_{\mathrm{VH}} / \mathrm{I}_{\mathrm{VV}}$ (grating correction factor) corrects the polarisation effects of the monochromator.

\subsection{Cells}

To estimate the cytotoxicity and cellular uptake of CRD13-FITC normal cell line (PBMC) and two cancer cell lines (1301-suspension, human T cell leukaemia and HL-60-suspension, promyelocytic human leukaemia) were used. PBMC was isolated from blood samples by centrifugation in a Histopaque 1077 gradient $\left(1500 \mathrm{rpm}, 15 \mathrm{~min}\right.$. at $\left.24^{\circ} \mathrm{C}\right)$ and washed twice in PBS at pH 7.4. The cells were resuspended in RPMI 1640 medium with heat-inactivated 10\% FBS and antibiotics (1\%) PBMC, 1301 and HL-60 cells were maintained in plastic tissue culture flasks (Falcon) kept at $37{ }^{\circ} \mathrm{C}$ in a humidified atmosphere of $5 \% \mathrm{CO}_{2} / 95 \%$ air. 


\subsection{Cytotoxicity}

The cytotoxicity of CRD13-FITC dendrimer was estimated using Alamar Blue assay. After 24 and $72 \mathrm{~h}$ treatment, viability was calculated from the equation:

$$
\% \text { viability }=\left(\mathrm{A}-\mathrm{A}_{0}\right) /\left(\mathrm{A}_{\mathrm{c}}-\mathrm{A}_{0}\right) \times 100 \%
$$

where $\mathrm{A}$ is the absorbance of sample, $\mathrm{A}_{\mathrm{c}}$ is the absorbance of control (non-treated cells), and $\mathrm{A}_{0}$ is the absorbance of $10 \%$ DMSO treated cells (100\% cell death, positive control).

\subsection{Cellular Uptake}

CRD13-FITC dendrimers at 2.5 and $5 \mu \mathrm{mol} / \mathrm{L}$ were used to examine cellular uptake by HL-60 and 1301 cells. The cells were seeded $2 \times 10$ cells/mL in $1 \mathrm{~mL}$ RPMI $(10 \%$ FBS, $100 \mathrm{U} / \mathrm{mL}$ penicillin, and $0.1 \mathrm{mg} / \mathrm{mL}$ streptomycin) on a 24 -well plate $\left(2,000,000\right.$ cells/well) and incubated at $37^{\circ} \mathrm{C}$ in a humidified atmosphere with $5 \% \mathrm{CO}_{2}$ in air. After 24 and $72 \mathrm{~h}$ incubation, the cells were washed with PBS (1500 rpm, $5 \mathrm{~min}$ ) and transferred to cytometry tubes. Immediately before measurement, $0.4 \%$ Trypan Blue was added to the samples (1:1) to exclude dead cells and cells with attached dendrimers on their surface. The samples were measured in a Becton Dickinson LSRII flow cytometere (BD, Franklin Lakes, New Jersey, USA), with acquisition of 10,000 events using $488 \mathrm{~nm}$ excitation wavelength. Emission signal was registered at $530 \mathrm{~nm} \pm 30 \mathrm{~nm}$ wavelength. The data were analysed using FlowJo 10 software (BD, Franklin Lakes, New Jersey, USA).

For confocal microscopy, 1301 and HL-60 cells after $24 \mathrm{~h}$ incubation with CRD13-FITC dendrimer at 2.5 and $5 \mu \mathrm{mol} / \mathrm{L}$ were stained with Dapi (Thermo Fisher Scientific, Waltham, USA) and Texas Red-X Phalloidin (Thermo Fisher Scientific, Waltham, USA). Images were taken with a Leica TCS SP8 microscope (Wetzlar, Germany) at different wavelengths (405, 495 and $565 \mathrm{~nm}$ ). Leica software (Wetzlar, Germany) was used to analyse the data.

\subsection{Statistical Analysis}

For haemotoxicity, results were obtained from a minimum of three independent repeats and are presented as mean \pm SD. For the Alamar Blue test, the results are shown as mean \pm SD. Statistical analyses were performed using Student's test, with significance set at $p<0.05$.

\section{Results}

\subsection{Synthesis of Ruthenium-Terminated Carbosilane Dendrimer with FITC (CRD-FITC)}

Synthesis and structural characterisation of CRD13-FITC is presented in detail in Figure 1, in the Methods Section 2. and the Supplementary Materials. In brief, a statistical hetero-functionalisation of carbosilane dendrimer G1-[NH2 $]_{4}$ generated dendrimers G1-[(NCPh(o-N) $\left.{ }_{3} \mathrm{NH}_{2}\right]$ (1), with a distribution of iminopyridine groups and amino moieties in a 3:1 ratio. The metal complexation to the iminopyridine moieties proceeded with a good yield, and this was confirmed by the displacement of the proton signal closest to the metal centre in the ${ }^{1} \mathrm{H}-\mathrm{NMR}$ spectra (Figures 2 and 3 ). Metallodendrimer $\mathrm{G} 1-\left[\left(\mathrm{NCPh}(\mathrm{o}-\mathrm{N}) \mathrm{Ru}(\eta 6-\mathrm{p} \text {-cymene }) \mathrm{Cl}_{2}\right)_{3} \mathrm{NH}_{2}\right]$ (2) was isolated as a water-soluble red solid, wherein the presence of a free amino group was confirmed by NMR and a Kaiser test. In the final step, FITC reacted with compound 2 to generate an isothiocyanate bond through the free amino group. FITC-labelled hetero-functional CRD13 was characterised through NMR, DOSY and UV-Vis experiments, confirming the binding of fluorescein, and ruling out the presence of excess fluorescein by IR. Dendrimer properties are: first generation, soluble in $\mathrm{MeOH} / \mathrm{EtOH} / \mathrm{H}_{2} \mathrm{O}$, and molecular weight of $2234.66 \mathrm{~g} / \mathrm{Mol}$. 

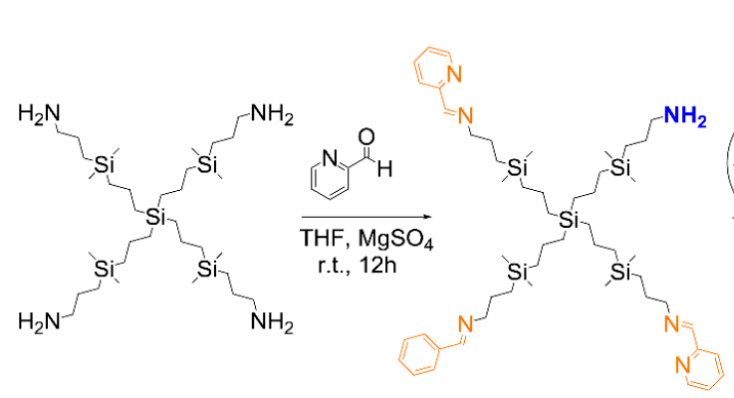

(1) $80 \%$

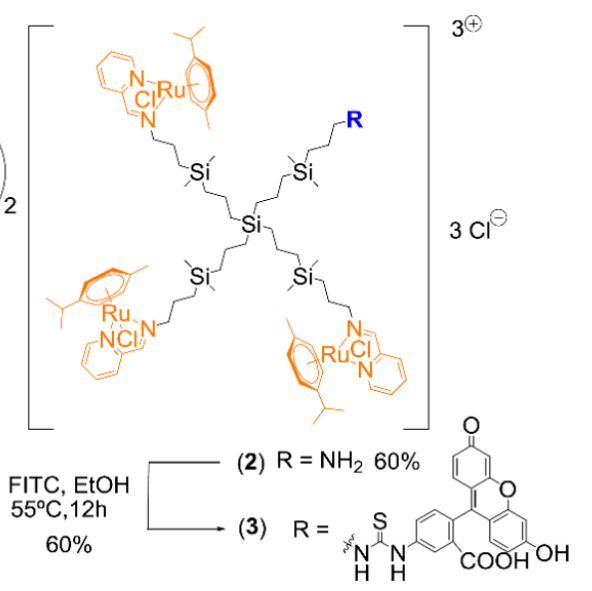

Figure 1. Synthesis of ruthenium-terminated carbosilane dendrimer with FITC (CRD13-FITC).

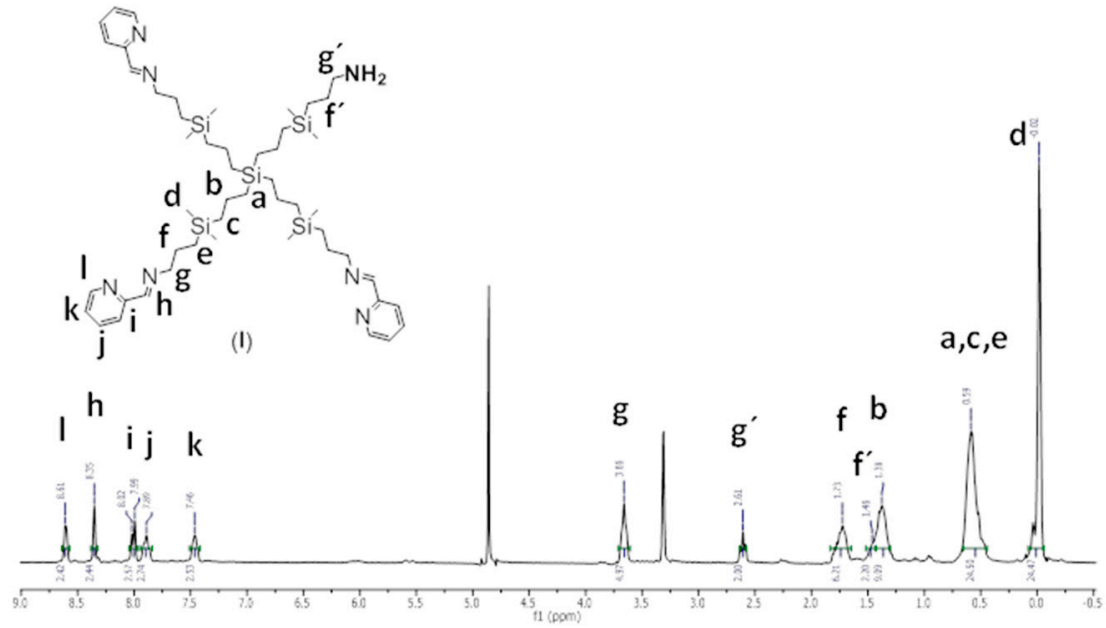

Figure 2. ${ }^{1} \mathrm{H}-\mathrm{NMR}$ spectrum of compound 1 in $\mathrm{CD}_{3} \mathrm{OD}$.

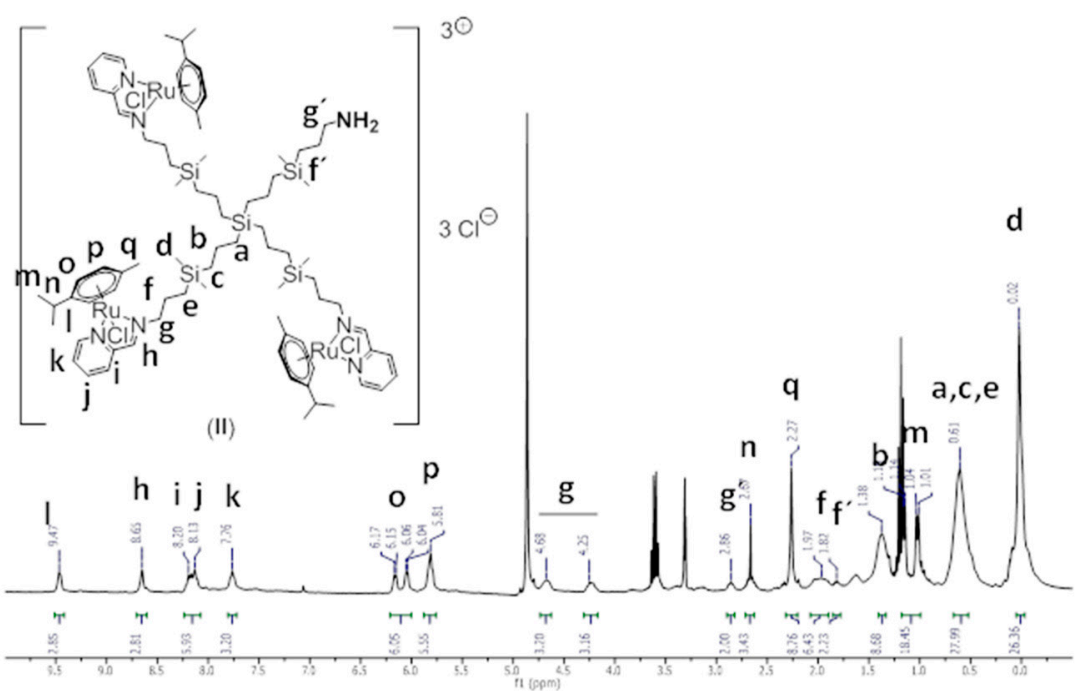

Figure 3. ${ }^{1} \mathrm{H}-\mathrm{NMR}$ spectrum of compound 2 in $\mathrm{CD}_{3} \mathrm{OD}$.

The final product in our conditions showed a high stability in all experiments. 
Structural Characterization

$\mathrm{G}_{1}-\left[(\mathrm{NCPh}(\mathrm{o}-\mathrm{N}))_{3} \mathrm{NH}_{2}\right](\mathbf{1}),{ }^{1} \mathrm{H}-\mathrm{NMR}\left(\mathrm{CD}_{3} \mathrm{OD}\right): \delta(\mathrm{ppm}) 0.02\left(\mathrm{~s}, 24 \mathrm{H},-\left(\mathrm{CH}_{3}\right)_{2} \mathrm{Si}-\right) ; 0.59(\mathrm{~m}$, $\left.24 \mathrm{H},-\mathrm{SiCH}_{2}\right)$; $1.38\left(\mathrm{~m}, 8 \mathrm{H},-\mathrm{SiCH}_{2} \mathrm{CH}_{2} \mathrm{CH}_{2} \mathrm{Si}\right) ; 1.46\left(\mathrm{~m}, 2 \mathrm{H},-\mathrm{SiCH}_{2} \mathrm{CH}_{2} \mathrm{CH}_{2} \mathrm{NH}_{2}\right) ; 1.73(\mathrm{~m}, 6 \mathrm{H}$, $\left.-\mathrm{SiCH}_{2} \mathrm{CH}_{2} \mathrm{CH}_{2} \mathrm{~N}\right) ; 2.61\left(\mathrm{t}, 2 \mathrm{H},-\mathrm{CH}_{2} \mathrm{NH}_{2}\right) ; 3.66\left(\mathrm{~m}, 6 \mathrm{H},-\mathrm{CH}_{2} \mathrm{~N}\right) ; 7.46\left(\mathrm{~m}, 3 \mathrm{H}, \mathrm{NCHCH}{ }^{\mathrm{Ar}}\right) ; 7.89(\mathrm{t}, 3 \mathrm{H}$, $\left.\mathrm{CCHCH}^{\mathrm{Ar}}\right) ; 8.00\left(\mathrm{~d}, 3 \mathrm{H}, \mathrm{CCH}^{\mathrm{Ar}}\right) ; 8.35(\mathrm{~s}, 3 \mathrm{H},-\mathrm{CH}=\mathrm{N}) ; 8.61\left(\mathrm{~m}, 3 \mathrm{H}, \mathrm{NCH}^{\mathrm{Ar}}\right)$. Elemental Analysis (\%): Calc. $\mathrm{C}_{50} \mathrm{H}_{89} \mathrm{~N}_{7} \mathrm{Si}_{5}$ (928.72): C, 64.66; H, 9.66; N, 10.56; Found: $\mathrm{C}, 64.30 ; \mathrm{H}, 9.00 ; \mathrm{N}, 10.48$.

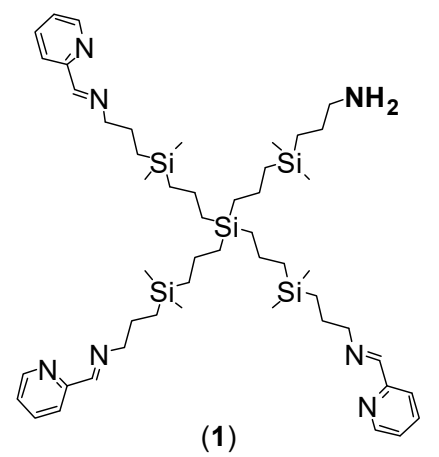

$\mathrm{G}_{1}-\left[\left(\mathrm{NCPh}(\mathrm{o}-\mathrm{N}) \mathrm{Ru}\left(\eta^{6} \text {-p-cymene }\right) \mathrm{Cl}_{2}\right)_{3} \mathrm{NH}_{2}\right](2){ }_{1}^{1} \mathrm{H}-\mathrm{NMR}\left(\mathrm{CD}_{3} \mathrm{OD}\right): \delta(\mathrm{ppm}) 0.02(\mathrm{~s}, 24 \mathrm{H}$, $\left.-\left(\mathrm{CH}_{3}\right)_{2} \mathrm{Si}-\right) ; 0.61\left(\mathrm{~m}, 24 \mathrm{H},-\mathrm{SiCH}_{2}-\right) ; 1.02 \& 1.15\left(2 \mathrm{~d}, 18 \mathrm{H}, \mathrm{CH}\left(\mathrm{CH}_{3}\right)_{2}{ }^{\mathrm{cym}}\right) ; 1.38\left(\mathrm{~m}, 8 \mathrm{H},-\mathrm{SiCH}_{2} \mathrm{CH}_{2} \mathrm{CH}_{2} \mathrm{Si}\right)$; $1.82\left(\mathrm{~m}, 2 \mathrm{H},-\mathrm{SiCH}_{2} \mathrm{CH}_{2} \mathrm{CH}_{2} \mathrm{NH}_{2}\right) ; 1.97\left(\mathrm{~m}, 6 \mathrm{H},-\mathrm{SiCH}_{2} \mathrm{CH}_{2} \mathrm{CH}_{2} \mathrm{~N}\right) ; 2.27\left(\mathrm{~s}, 9 \mathrm{H}, \mathrm{CCH}_{3}{ }^{\mathrm{cym}}\right) ; 2.67(\mathrm{~m}, 3 \mathrm{H}$, $\left.\mathrm{CH}\left(\mathrm{CH}_{3}\right)_{2}{ }^{\mathrm{cym}}\right) ; 2.86\left(\mathrm{t}, 2 \mathrm{H},-\mathrm{CH}_{2} \mathrm{NH}_{2}\right) ; 4.25 \& 4.68\left(2 \mathrm{~m}, 6 \mathrm{H},-\mathrm{CH}_{2} \mathrm{~N}\right) ; 5.81\left(\mathrm{~m}, 6 \mathrm{H}, \mathrm{CHCCH}_{3}{ }^{\mathrm{cym}}\right) ; 6.10$ $\left(\mathrm{dd}, 6 \mathrm{H}, \mathrm{CHCCH}\left(\mathrm{CH}_{3}\right)_{2}{ }^{\mathrm{cym}}\right) ; 7.76\left(\mathrm{~m}, 3 \mathrm{H}, \mathrm{NCHCH}^{\mathrm{Ar}}\right) ; 8.13\left(\mathrm{~m}, 3 \mathrm{H}, \mathrm{CCHCH}^{\mathrm{Ar}}\right) ; 8.20\left(\mathrm{~m}, 3 \mathrm{H}, \mathrm{CCH}^{\mathrm{Ar}}\right)$; $8.65(\mathrm{~s}, 3 \mathrm{H},-\mathrm{CH}=\mathrm{N}) ; 9.47\left(\mathrm{~m}, 3 \mathrm{H}, \mathrm{NCH}^{\mathrm{Ar}}\right)$. Elemental Analysis (\%): Calc. For $\mathrm{C}_{80} \mathrm{H}_{131} \mathrm{Cl}_{6} \mathrm{~N}_{7} \mathrm{Ru}_{3} \mathrm{Si}_{5}$ (1847.30): C, 52.01; H, 7.15; N, 5.31; Found: C, 51.74; H, 7.08; N, 5.30.

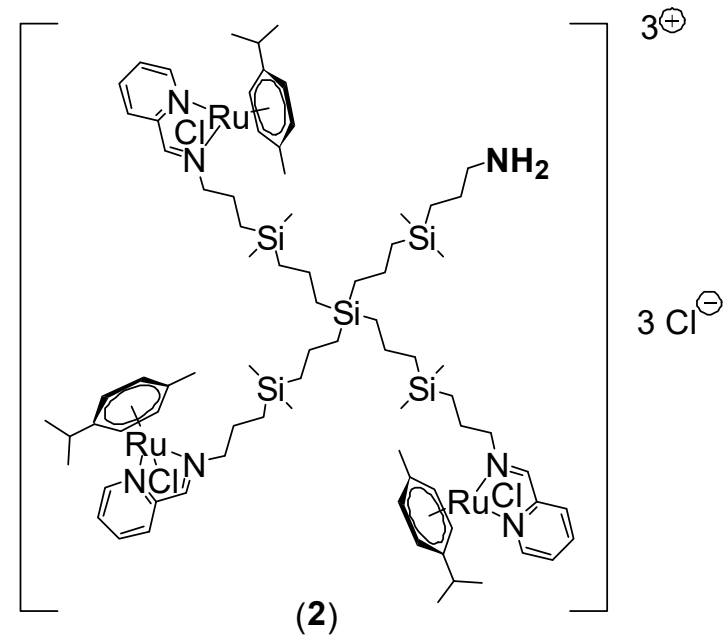

$\mathrm{G}_{1}\left[\left(\mathrm{NCPh}(\mathrm{o}-\mathrm{N}) \mathrm{Ru}\left(\eta^{6} \text {-p-cymene }\right) \mathrm{Cl}_{2}\right)_{3} \mathrm{NH}_{2}\right.$-FITC $](3),{ }^{1} \mathrm{H}-\mathrm{NMR}\left(\mathrm{CD}_{3} \mathrm{OD}\right): \delta(\mathrm{ppm}) 0.02(\mathrm{~s}, 24 \mathrm{H}$, $\left.-\left(\mathrm{CH}_{3}\right)_{2} \mathrm{Si}-\right) ; 0.61\left(\mathrm{~m}, 24 \mathrm{H},-\mathrm{SiCH}_{2}-\right) ; 1.02 \& 1.15\left(2 \mathrm{~d}, 18 \mathrm{H}, \mathrm{CH}\left(\mathrm{CH}_{3}\right)_{2} \mathrm{cym}\right) ; 1.38\left(\mathrm{~m}, 8 \mathrm{H},-\mathrm{SiCH}_{2} \mathrm{CH}_{2} \mathrm{CH}_{2} \mathrm{Si}\right)$; $1.82\left(\mathrm{~m}, 2 \mathrm{H},-\mathrm{SiCH}_{2} \mathrm{CH}_{2} \mathrm{CH}_{2} \mathrm{NH}_{2}\right) ; 1.97\left(\mathrm{~m}, 6 \mathrm{H},-\mathrm{SiCH}_{2} \mathrm{CH}_{2} \mathrm{CH}_{2} \mathrm{~N}\right) ; 2.27\left(\mathrm{~s}, 9 \mathrm{H}, \mathrm{CCH}_{3}{ }^{\mathrm{cym}}\right) ; 2.67(\mathrm{~m}$, $\left.3 \mathrm{H}, \mathrm{CH}\left(\mathrm{CH}_{3}\right)_{2}{ }^{\mathrm{cym}}\right) ; 3.30\left(\mathrm{t}, 2 \mathrm{H},-\mathrm{CH}_{2} \mathrm{NHSNH}\right) ; 4.25 \& 4.68\left(2 \mathrm{~m}, 6 \mathrm{H},-\mathrm{CH}_{2} \mathrm{~N}\right) ; 5.81\left(\mathrm{~m}, 6 \mathrm{H}, \mathrm{CHCCH}_{3}{ }^{\mathrm{cym}}\right)$; $6.10\left(\mathrm{dd}, 6 \mathrm{H}, \mathrm{CHCCH}\left(\mathrm{CH}_{3}\right)_{2}{ }^{\mathrm{cym}}\right) ; 6.60(\mathrm{~m}, \mathrm{FITC}) ; 7.76\left(\mathrm{~m}, 3 \mathrm{H}, \mathrm{NCHCH}^{\mathrm{Ar}}\right) ; 8.13\left(\mathrm{~m}, 3 \mathrm{H}, \mathrm{CCHCH}^{\mathrm{Ar}}\right)$; $8.20\left(\mathrm{~m}, 3 \mathrm{H}, \mathrm{CCH}^{\mathrm{Ar}}\right) ; 8.65(\mathrm{~s}, 3 \mathrm{H},-\mathrm{CH}=\mathrm{N}) ; 9.47\left(\mathrm{~m}, 3 \mathrm{H}, \mathrm{NCH}^{\mathrm{Ar}}\right)$. UV-Vis: $507 \mathrm{~nm}$ (FITC). Elemental Analysis (\%): Calc. For $\mathrm{C}_{101} \mathrm{H}_{140} \mathrm{Cl}_{6} \mathrm{~N}_{8} \mathrm{O}_{5} \mathrm{Ru}_{3} \mathrm{SSi}_{5}$ (2234.66): C, 54.24; $\mathrm{H}, 6.40 ; \mathrm{N}, 5.01 ; \mathrm{S}, 1.43$ Found: $\mathrm{C}$, $54.19 ; \mathrm{H}, 6.29 ; \mathrm{N}, 5.02 ; \mathrm{S}, 0.99$. 


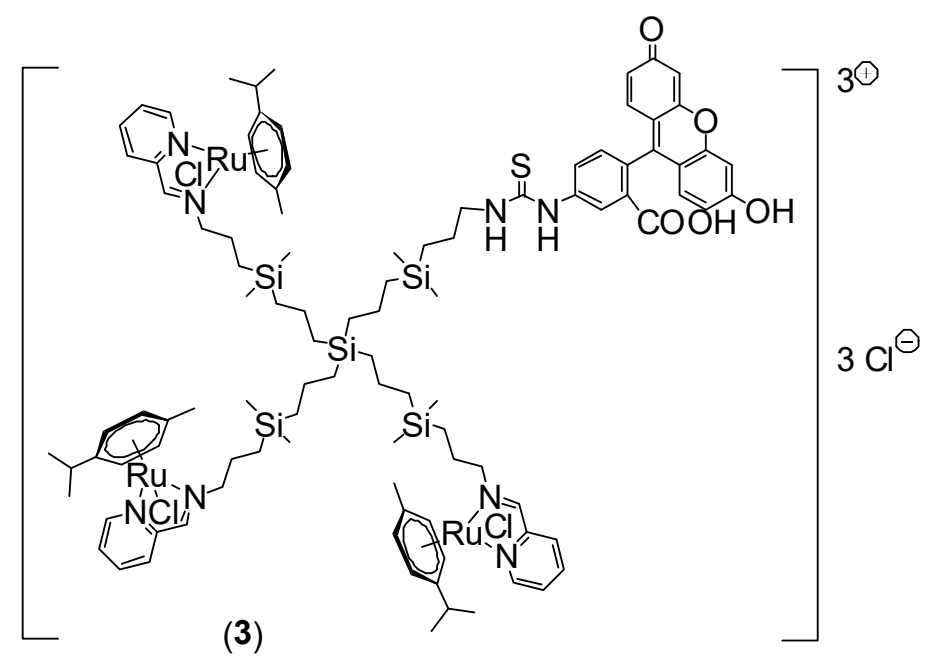

\subsection{Zeta Potential and Particle Size}

Zeta potential and zeta size of CRD13-FITC dendrimer were $25.8 \pm 3.2 \mathrm{mV}$ and $476 \pm 54$ $\mathrm{nm}$, respectively.

\subsection{Transmission Electron Microscopy}

The CRD13-FITC dendrimer produced characteristic branched structures but some single nanoparticles were also observed. The size of aggregates and single nanoparticles was from 50 to $500 \mathrm{~nm}$ and from 5 to $10 \mathrm{~nm}$, respectively (Figure 4).

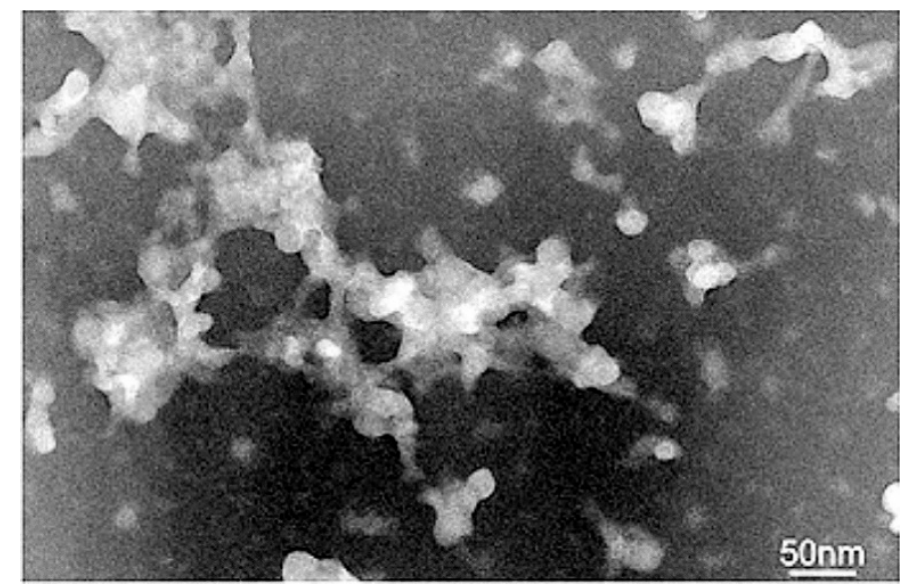

Figure 4. Ultrastructure of ruthenium terminated carbosilane dendrimer with FITC (CRD13-FITC). Dendrimer was dissolved in Na-phosphate buffer at $10 \mathrm{mmol} / \mathrm{L}$, and pH7.4. Bar $=50 \mathrm{~nm}$.

\subsection{Haemotoxicity}

Haemotoxicity is a simple method to investigate the disruption of cell membrane caused by chemical compounds. CRD13-FITC dendrimer haemolysed erythrocytes at 50 and $100 \mu \mathrm{mol} / \mathrm{L}$, but, at lower concentrations of $0.5-10 \mu \mathrm{mol} / \mathrm{L}$, the haemolysis did not exceed $30 \%$ of control (Figure 5 ). The haemolysis of erythrocytes in water was chosen as a positive control and it was added in the formula to calculate the haemolysis. 


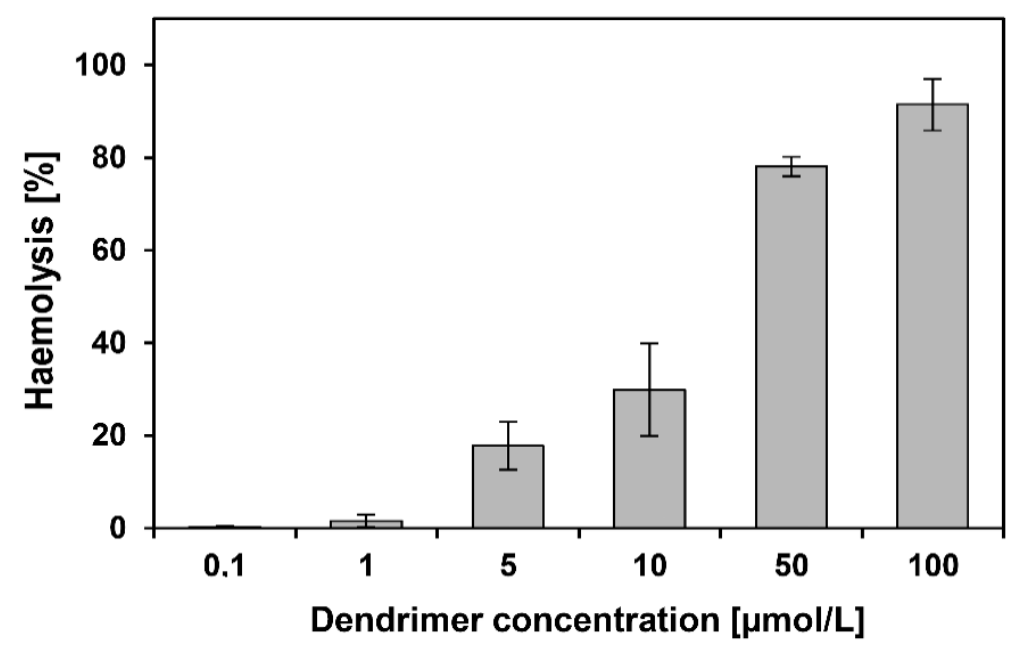

Figure 5. Haemolysis induced after $24 \mathrm{~h}$ treatment of red blood cells with ruthenium terminated carbosilane dendrimer with FITC (CRD13-FITC) at 0.1-100 $\mu \mathrm{mol} / \mathrm{L}$. Two percent haematocrit in PBS buffer at $\mathrm{pH} 7.4$ and $22{ }^{\circ} \mathrm{C}$. Results are mean $\pm \mathrm{SD}, n=6$.

\subsection{Fluorescence Anisotropy}

To explain the interaction of CRD13-FITC dendrimer with red blood cell membranes, anisotropy changes were investigated. Increased fluorescence anisotropy of TMA-DPH is responsible for the increase of the rigidity of hydrophilic regions of the membrane. In turn, the increase in DPH anisotropy corresponds to a decrease in the fluidity of the hydrophobic phospholipid bilayer. The presented results (Figure 6) indicate that CRD13-FITC at concentrations of $0.5-10 \mu \mathrm{mol} / \mathrm{L}$ changed anisotropy of samples. Increased fluorescence anisotropy of both probes was dose-dependent indicative of changes in membrane fluidity. Increase of DPH and TMA-DPH fluorescence anisotropy in the presence of CRD13-FITC dendrimer indicated that it interacts with both hydrophobic and hydrophilic regions of the membrane.

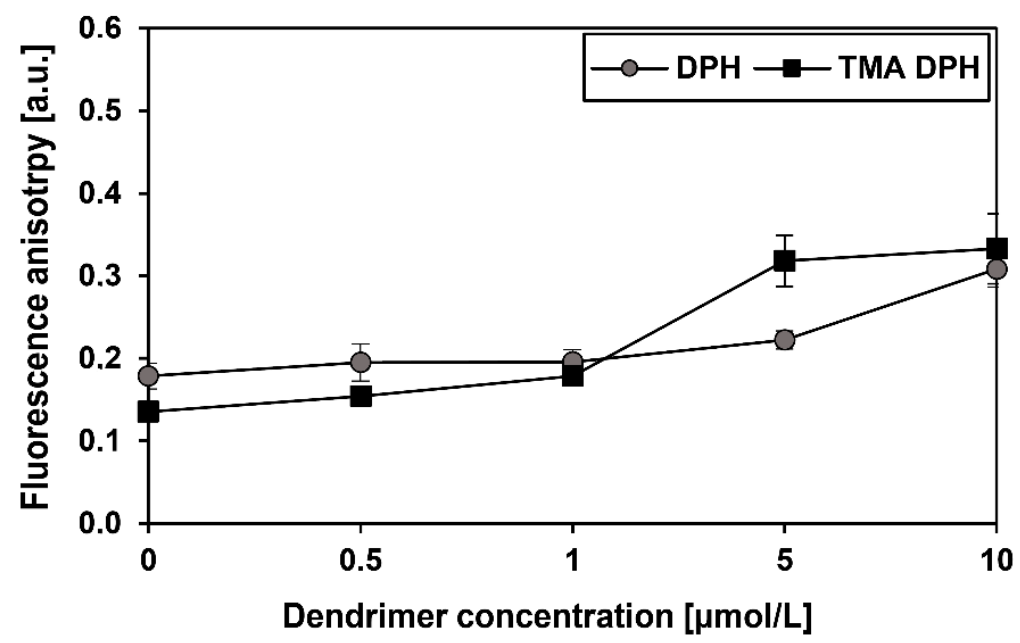

Figure 6. Changes in fluorescence anisotropy of DPH and TMA-DPH of erythrocyte membranes treated with ruthenium terminated carbosilane dendrimer with FITC (CRD13-FITC) at rising concentrations from 0.5 to $10 \mu \mathrm{mol} / \mathrm{L}, \mathrm{PBS}$ buffer, $\mathrm{pH} 7.4,37^{\circ} \mathrm{C}$. The values are the mean $\pm \mathrm{SD} \mathrm{n}=3$.

\subsection{Viability}

We estimated the effects of CRD13-FITC dendrimer on the viability of PBMC normal cells as well as HL60 and 1301 leukemic cells after 24 and $72 \mathrm{~h}$ incubation (Figure 7). The viability of cells upon treatment with DMSO (100\% cell death) was chosen as a positive control and it was added into the 
formula to calculate viability. Cell viability decrease was time- and dose-dependent. The dendrimers up to $10 \mu \mathrm{mol} / \mathrm{L}$, after 24 and $72 \mathrm{~h}$ of incubation, were less cytotoxic for normal cells than for both cancer cell lines. The viability of PBMC cells in the presence of dendrimer at up to $5 \mu \mathrm{mol} / \mathrm{L}$ was slightly reduced. In contrast, the viability of cancer HL-60 and 1301 cells was significantly decreased in the presence of CRD 13-FITC. The $\mathrm{IC}_{50}$ values after $72 \mathrm{~h}$ incubation were lower $(8.04 \pm 1.01$ for PBMC cells, $2.26 \pm 1.01$ for HL60, $5.45 \pm 1.01$ for 1301 cell lines, $p<0.05$ between normal and cancer cells, $p<0.05$ between HL60 and 1301) in comparison to $24 \mathrm{~h}$ incubation $(18.9 \pm 1.0$ for PBMC, $3.74 \pm 1.09$ for HL60 and $10.32 \pm 1.15$ for 1301 cells, $p<0.05$ between normal and cancer cells, $p<0.05$ between HL60 and 1301).

\section{$24 \mathrm{~h}$}

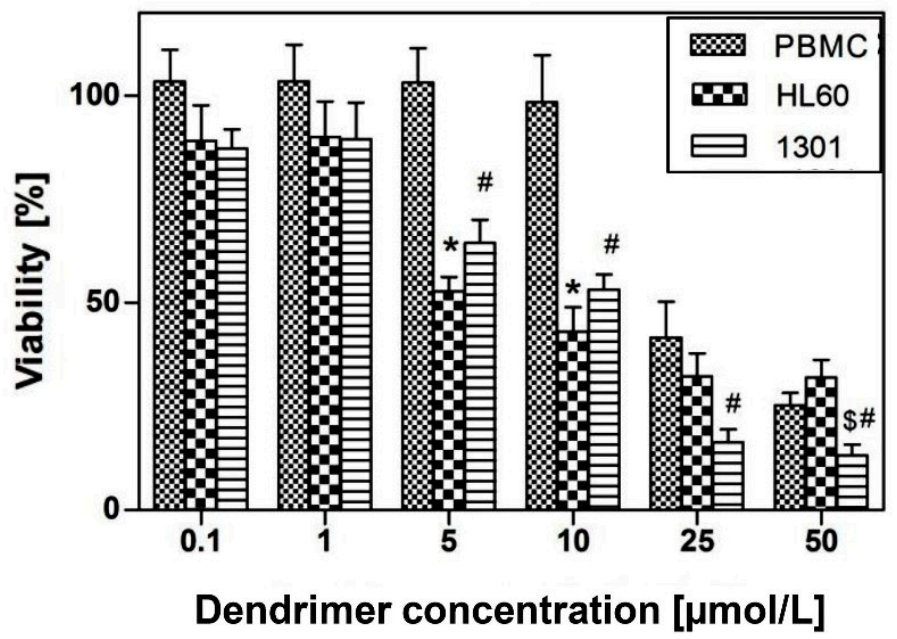

$72 \mathrm{~h}$

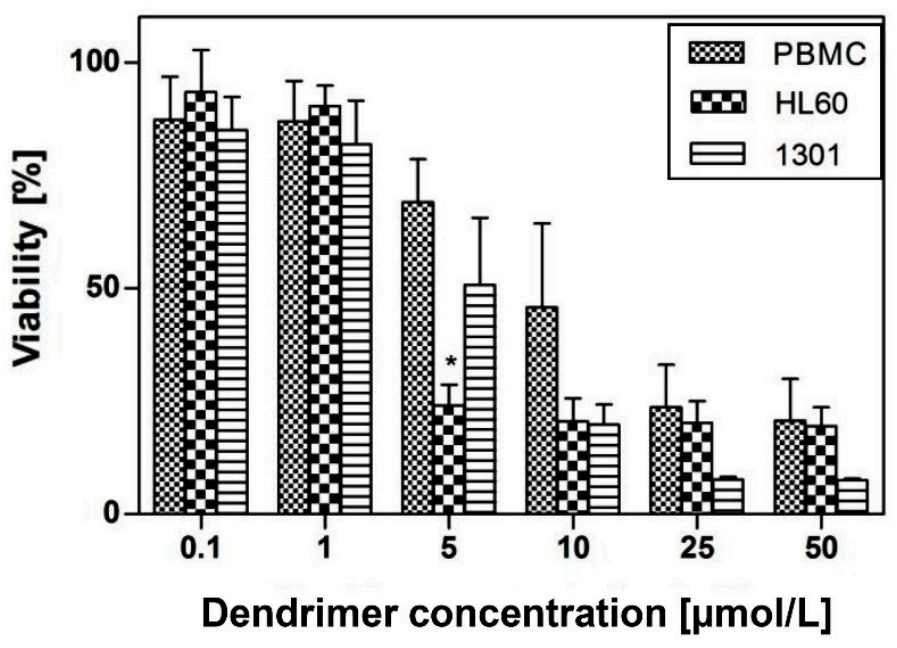

Figure 7. Effect of ruthenium terminated carbosilane dendrimer with FITC (CRD13-FITC) on the viability of PBMC, HL-60 and 1301 cells after $24 \mathrm{~h}$ and $72 \mathrm{~h}$ incubation. The values are the mean \pm $\mathrm{SD}, n=9$. Statistically significant differences in comparison to the control cells ${ }^{*} p<0.05, \# p<0.01$, $\$ p<0.001)$.

\subsection{Cellular Uptake}

Cellular uptake of CRD13 dendrimer labelled with fluorescein (CRD13 FITC) at 2.5 and $5 \mu \mathrm{mol} / \mathrm{L}$ by HL-60 and 1301 cell lines was monitored after 24 and 72 h (Figures 8 and 9). Cytometer and confocal 
investigations showed that the dendrimer was taken up more intensively by HL-60 cells than 1301 cells. The percentage of cellular uptake for HL-60 cells was higher at both concentrations after $24 \mathrm{~h}$ than after $72 \mathrm{~h}$. In both cell lines, internalisation of CRD-FITC dendrimer was higher at 5 than $2.5 \mu \mathrm{mol} / \mathrm{L}$. As a positive control, the cellular uptake of corresponding non-modified carbosilane ruthenium dendrimer was chosen that was equal to $30 \pm 3 \%$ at $24 \mathrm{~h}$ in HL60 cells.

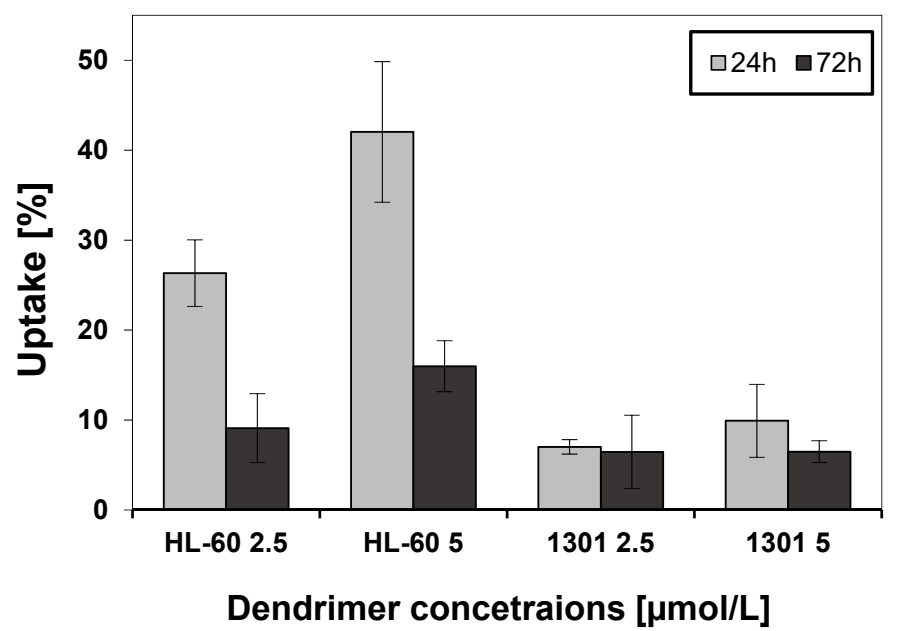

Figure 8. Flow cytometry of the uptake by HL-60 and 1301 cells of ruthenium terminated carbosilane dendrimer with FITC (CRD13-FITC). The results are mean $\pm \mathrm{SD}, n=3$.
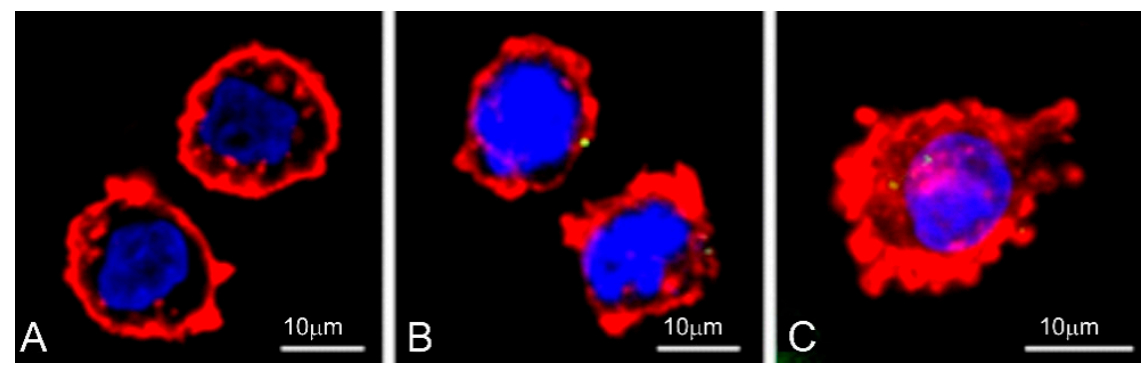

Figure 9. Confocal microscopy images of HL-60 cells after $24 \mathrm{~h}$ incubation with ruthenium terminated carbosilane dendrimer with FITC (CRD13-FITC). A-control, B-2.5 $\mu \mathrm{mol} / \mathrm{L}$ and C-5 $\mu \mathrm{mol} / \mathrm{L}$. Bar $=10 \mu \mathrm{m}$.

\section{Discussion}

The investigated dendrimer has a positive zeta potential of $25.8 \pm 3.2 \mathrm{mV}$. Similar results were demonstrated for CRD13 (without modification with fluorescein), i.e., $21.5 \pm 6.2 \mathrm{mV}$. The higher-generation dendrimer has a correspondingly higher zeta potential [5]. Positive charges of both dendrimers indicate that they should readily interact with negatively charged cell membrane $[5,23,24]$. Due to interaction between dendrimers, they can form aggregates. In aqueous solution, the size of the CRD13-FITC nanoparticle was $476.8 \pm 54.4 \mathrm{~nm}$, but this dendrimer created characteristic 50-500 nm branched structures in the dry state. Sometimes 4-10 nm single nanoparticles were observed. Differences between the results obtained in a solution and in a dry state are well known $[5,25,26]$. The zeta size of the unmodified CRD13 dendrimer was $455.7 \pm 139.0 \mathrm{~nm}$ (as was CRD13 dendrimer), whereas 50-800 nm aggregates were visible on the TEM images [5]. Their respective results appear very similar, which indicates that addition of fluorescein changes neither the size nor the potential of the dendrimer. Our dendrimer caused haemolysis after $24 \mathrm{~h}$ incubation mainly at higher concentrations. Similarly, CRD13 disrupted membranes at concentrations from 25 to $100 \mu \mathrm{mol} / \mathrm{L}$ after $24 \mathrm{~h}$ incubation [5]. The fact that haemolytic activity depends on dendrimer concentration has already been shown earlier for carbosilane [27,28], phosphorus [29] and PAMAM dendrimers $[30,31]$. Due to surface charge, cationic dendrimers can react with negatively charged 
and damage red blood cell membranes more than neutral or anionic ones [32-34]. Therefore, on the one hand, positive surface charge increases the chance that a nanoparticle will cross the membrane barrier, while, on the other hand, it can lead to membrane damage and cell death [35]. CRD13-FITC at concentrations of $0.5-10 \mu \mathrm{mol} / \mathrm{L}$ interacting with both hydrophobic and hydrophilic regions of the membrane changes their fluidity. A similar effect was observed for the unmodified CRD13 dendrimer (unpublished data). Interactions of other carbosilane dendrimers with hydrophobic and hydrophilic regions of the membrane have also previously been demonstrated [36]. The PBMC, HL-60 and 1301 cell viability after incubation with CRD13-FITC dendrimer decreased with time. Cytotoxicity to normal PBMC cells was lower than with both cancer cell lines. The viability of PBMC cells in the presence of CRD13-FITC dendrimer at up to $5 \mu \mathrm{mol} / \mathrm{L}$ was slightly reduced after 24 and $72 \mathrm{~h}$ treatment. In contrast, the viability of HL-60 and 1301 cancer cells was significantly decreased in the presence of CRD 13-FITC at the same concentration. This is in agreement with the previous work for PBMC (unpublished data), HL-60 and 1301 cells treated with unlabelled CRD13 dendrimer [5]. A similar effect of carbosilane dendrimers on other cancer cell types was reported by Maroto-Diaz et al. [37]. Absence of a negative influence of carbosilane dendrimers on the normal cells was also noted $[27,38]$. In contrast, significant effects of ruthenium containing complexes were reported [39,40]. Ruthenium is a metal with anti-tumour properties [39,41]. Our dendrimer was more toxic for cancer than normal cells, probably due to the presence of ruthenium. $\mathrm{IC}_{50}$ values after $72 \mathrm{~h}$ incubation with CRD13-FITC dendrimer were lower in comparison to after $24 \mathrm{~h}$, giving results in agreement with others in the literature [5]. Flow cytometry and confocal microscopy techniques were used to assess the uptake efficiency of CRD13 FITC. The dendrimer at $5 \mu \mathrm{mol} / \mathrm{L}$ was taken up by HL-60 and 1301 cell lines, and was more effective than at $2.5 \mu \mathrm{mol} / \mathrm{L}$. Both techniques showed that CRD13-FITC dendrimer was more intensively internalized by HL-60 than 1301 cells. Moreover, the uptake of the dendrimer was more intensive after 24 than after $72 \mathrm{~h}$ in HL-60 cells, probably due to its higher toxicity after longer incubation. PAMAM FITC labelled dendrimers can enter $\mathrm{C} 6$ cells after $12 \mathrm{~h}$ [42]. A similar effect was observed for complexes of CRD13 dendrimer and fluorescently labelled siRNA taken up by HL-60 cells after $3 \mathrm{~h}$ [43]. Other dendritic molecular particles have been described as good transporters of bioactive cargos into cells [44].

\section{Conclusions}

Thus, the labelling of carbosilane ruthenium dendrimer by FITC did not decrease its uptake into cells in comparison with the non-labelled one. On the other hand, the addition of a fluorescent probe allowed tracking the metallodendrimer in normal and cancer cells. It was found that carbosilane ruthenium dendrimer labelled with FITC in concentration up to $10 \mu \mathrm{mol} / \mathrm{L}$ was more cytotoxic for cancer cells than for normal cells. These data are in good agreement with our data with non-labelled carbosilane ruthenium dendrimer. FITC-labelled carbosilane ruthenium dendrimer was internalized more intensively into HL-60 (suspension culture) than into 1301 adhesive cells. Thus, FITC labelled carbosilane ruthenium dendrimer is a good candidate for diagnostic imaging and studying anticancer effects of metallodendrimers in cancer therapy.

Supplementary Materials: The following are available online at http://www.mdpi.com/2218-273X/9/9/411/s1, Figure S1: ${ }^{1} \mathrm{H}-\mathrm{NMR}$ spectrum of compound $\mathbf{1}$ in $\mathrm{CD}_{3} \mathrm{OD}$, Figure S2. ${ }^{1} \mathrm{H}-\mathrm{NMR}$ spectrum of compound $\mathbf{2}$ in $\mathrm{CD}_{3} \mathrm{OD}$, Figure S3. DOSY spectrum of compound 3 in $\mathrm{CD}_{3} \mathrm{OD}$.

Author Contributions: Conceptualization, M.I.; Methodology, S.M.; Software, M.K.; Validation, D.S., F.J.d.1.M., R.G.R. and M.B.; Investigation, M.K. and S.M.; Resources, M.M.-D., N.S.d.O., P.O. and F.J.d.1.M.; Data Curation, M.I.; Writing-Original Draft Preparation, S.M. and M.K.; Review and Editing, M.I.; Visualisation, S.M.; and Supervision and Project Administration, M.I and M.B.

Funding: This research received no external funding.

Acknowledgments: This work was supported by grants from CTQ2017-86224-P (MINECO), Consortium IMMUNOTHERCAN-CM B2017/BMD-3733 (CAM) to UAH CIBER-BBN; the "EUROPARTNER" and PL-SK PPN/BIL/2018/1/00150 Projects granted by Polish National Agency for Academic Exchange; and "NanoTENDO" project, supported by the National Science Centre, Poland under the M-ERA.NET 2, N 685451. 
Conflicts of Interest: The authors declare no conflicts of interest.

\section{References}

1. Vankayala, R.; Hwang, K.C. Near-Infrared-Light-Activatable Nanomaterial-Mediated Phototheranostic Nanomedicines: An Emerging Paradigm for Cancer Treatment. Adv. Mater. 2018, 30, 1706320. [CrossRef] [PubMed]

2. Wan, D.; Tang, B.; Wang, Y.-J.; Guo, B.-H.; Yin, H.; Yi, Q.-Y.; Liu, Y.-J. Synthesis and anticancer properties of ruthenium (II) complexes as potent apoptosis inducers through mitochondrial disruption. Eur. J. Med. Chem. 2017, 139, 180-190. [CrossRef] [PubMed]

3. Wang, F.-Y.; Xi, Q.-Y.; Huang, K.-B.; Tang, X.-M.; Chen, Z.-F.; Liu, Y.-C.; Liang, H. Crystal structure, cytotoxicity and action mechanism of $\mathrm{Zn}(\mathrm{II}) / \mathrm{Mn}(\mathrm{II})$ complexes with isoquinoline ligands. J. Inorg. Biochem. 2017, 169, 23-31. [CrossRef] [PubMed]

4. Gan, Q.; Xiong, Y.-H.; Fu, Y.-L.; Zhang, C.-L.; Wang, B.-F.; Mao, Z.-W.; Le, X.-Y. Two new mixed copper(ii)-dipeptide complexes of $\mathrm{N}, \mathrm{N}$-donor heterocycle ligands: studies on their non-covalent DNA binding, chemical nuclease, antioxidant and anticancer activities. RSC Adv. 2016, 6, 35952-35965. [CrossRef]

5. Michlewska, S.; Ionov, M.; Shcharbin, D.; Maroto-Díaz, M.; Ramirez, R.G.; De La Mata, F.J.; Bryszewska, M. Ruthenium metallodendrimers with anticancer potential in an acute promyelocytic leukemia cell line (HL60). Eur. Polym. J. 2017, 87, 39-47. [CrossRef]

6. Kenny, R.G.; Marmion, C.J. Toward Multi-Targeted Platinum and Ruthenium Drugs-A New Paradigm in Cancer Drug Treatment Regimens? Chem. Rev. 2019, 119, 1058-1137. [CrossRef] [PubMed]

7. Hanif, M.; Hartinger, C.G. Anticancer metallodrugs: where is the next cisplatin? Futur. Med. Chem. 2018, 10, 615-617. [CrossRef] [PubMed]

8. Lazarević, T.; Rilak, A.; Bugarčić, Ž.D. Platinum, palladium, gold and ruthenium complexes as anticancer agents: Current clinical uses, cytotoxicity studies and future perspectives. Eur. J. Med. Chem. 2017, 142, 8-31. [CrossRef] [PubMed]

9. Abid, M.; Shamsi, F.; Azam, A. Ruthenium Complexes: An Emerging Ground to the Development of Metallopharmaceuticals for Cancer Therapy. Min. Rev. Med. Chem. 2015. [CrossRef]

10. Hamid, S.; Donaldson, I.A.; Hu, Y.; Rodell, R.; Villarini, B.; Bonmati, E.; Tranter, P.; Punwani, S.; Sidhu, H.S.; Willis, S.; et al. The SmartTarget Biopsy Trial: A Prospective, Within-person Randomised, Blinded Trial Comparing the Accuracy of Visual-registration and Magnetic Resonance Imaging/Ultrasound Image-fusion Targeted Biopsies for Prostate Cancer Risk Stratification. Eur. Urol. 2019, 75, 733-740. [CrossRef] [PubMed]

11. Ahn, S.J.; Kim, J.H.; Park, S.J.; Han, J.K. Prediction of the therapeutic response after FOLFOX and FOLFIRI treatment for patients with liver metastasis from colorectal cancer using computerized CT texture analysis. Eur. J. Radiol. 2016, 85, 1867-1874. [CrossRef] [PubMed]

12. Tanzina, H.S.; Chowdhury, E. Recent progress in delivery of therapeutic and imaging agents utilizing organic-inorganic hybrid nanoparticles. Curr. Drug Deliv. 2018, 15, 485-496. [CrossRef]

13. A Tomalia, D.; Baker, H.; Dewald, J.; Hall, M.; Kallos, G.; Martin, S.; Roeck, J.; Ryder, J.; Smith, P. A New Class of Polymers: Starburst-Dendritic Macromolecules. Polym. J. 1985, 17, 117-132. [CrossRef]

14. Menjoge, A.R.; Kannan, R.M.; Tomalia, D.A. Dendrimer-based drug and imaging conjugates: design considerations for nanomedical applications. Drug Discov. Today 2010, 15, 171-185. [CrossRef] [PubMed]

15. Ionov, M.; Lazniewska, J.; Dzmitruk, V.; Halets, I.; Loznikova, S.; Novopashina, D.; Apartsin, E.; Venyaminova, A.; Miłowska, K.; Nowacka, O.; et al. Anticancer siRNA cocktails as a novel tool to treat cancer cells. Part (A). Mechanisms of interaction. Int. J. Pharm. 2015, 485, 261-269. [CrossRef] [PubMed]

16. Kannan, R.M.; Nance, E.; Kannan, S.; Tomalia, D.A. Emerging concepts in dendrimer-based nanomedicine: from design principles to clinical applications. J. Intern. Med. 2014, 276, 579-617. [CrossRef]

17. Govender, P.; Renfrew, A.K.; Clavel, C.M.; Dyson, P.J.; Therrien, B.; Smith, G.S. Antiproliferative activity of chelating $\mathrm{N}, \mathrm{O}$ - and $\mathrm{N}, \mathrm{N}$-ruthenium(ii) arene functionalised poly(propyleneimine) dendrimer scaffolds. Dalton Trans. 2011, 40, 1158-1167. [CrossRef]

18. Heffeter, P.; Riabtseva, A.; Senkiv, Y.; Kowol, C.R.; Körner, W.; Jungwith, U.; Mitina, N.; Keppler, B.K.; Konstantinova, T.; Yanchuk, I.; et al. Nanoformulation Improves Activity of the (pre)Clinical Anticancer Ruthenium Complex KP1019. J. Biomed. Nanotechnol. 2014, 10, 877-884. [CrossRef] 
19. Fischer, B.; Heffeter, P.; Kryeziu, K.; Gille, L.; Meier, S.M.; Berger, W.; Kowol, C.R.; Keppler, B.K.; Meier-Menches, S.M. Poly(lactic acid) nanoparticles of the lead anticancer ruthenium compound KP1019 and its surfactant-mediated activation. Dalton Trans. 2014, 43, 1096-1104. [CrossRef]

20. Xu, M.; Wen, Y.; Liu, Y.; Tan, X.; Chen, X.; Zhu, X.; Wei, C.; Chen, L.; Wang, Z.; Liu, J.; et al. Hollow mesoporous ruthenium nanoparticles conjugated bispecific antibody for targeted anti-colorectal cancer response of combination therapy. Nanoscale 2019, 11, 9661-9678. [CrossRef]

21. Dou, Y.-K.; Shang, Y.; He, X.-W.; Li, W.-Y.; Li, Y.-H.; Zhang, Y.-K. Preparation of a Ruthenium-Complex-Functionalized Two-Photon-Excited Red Fluorescence Silicon Nanoparticle Composite for Targeted Fluorescence Imaging and Photodynamic Therapy in Vitro. ACS Appl. Mater. Interfaces 2019, 11, 13954-13963. [CrossRef] [PubMed]

22. Lowry, O.H.; Rosebrough, N.J.; Farr, A.L.; Randall, R.J. Protein measurement with the Folin phenol reagent. J. Boil. Chem. 1951, 193, 265-275.

23. Martinho, N.; Florindo, H.; Silva, L.; Brocchini, S.; Zloh, M.; Barata, T. Molecular Modeling to Study Dendrimers for Biomedical Applications. Molecules 2014, 19, 20424-20467. [CrossRef] [PubMed]

24. Ionov, M.; Ciepluch, K.; Garaiova, Z.; Melikishvili, S.; Michlewska, S.; Balcerzak, Ł.; Glińska, S.; Miłowska, K.; Gomez-Ramirez, R.; De La Mata, F.J.; et al. Dendrimers complexed with HIV-1 peptides interact with liposomes and lipid monolayers. Biochim. Biophys. Acta (BBA) Biomembr. 2015, 1848, 907-915. [CrossRef] [PubMed]

25. Ionov, M.; Ciepluch, K.; Klajnert, B.; Glińska, S.; Gomez-Ramirez, R.; De La Mata, F.J.; Muñoz-Fernández, M.Á.; Bryszewska, M.; Klajnert-Maculewicz, B. Complexation of HIV derived peptides with carbosilane dendrimers. Colloids Surf. B 2013, 101, 236-242. [CrossRef] [PubMed]

26. Ionov, M.; Ihnatsyeu-Kachan, A.; Michlewska, S.; Shcharbina, N.; Shcharbin, D.; Majoral, J.-P.; Bryszewska, M. Effect of dendrimers on selected enzymes-Evaluation of nano carriers. Int. J. Pharm. 2016, 499, 247-254. [CrossRef] [PubMed]

27. Pedziwiatr-Werbicka, E.; Fuentes, E.; Dzmitruk, V.; Sánchez-Nieves, J.; Sudas, M.; Drozd, E.; Shakhbazau, A.; Shcharbin, D.; De La Mata, F.J.; Gomez-Ramirez, R.; et al. Novel 'SiC' carbosilane dendrimers as carriers for anti-HIV nucleic acids: Studies on complexation and interaction with blood cells. Colloids Surf. B 2013, 109, 183-189. [CrossRef]

28. Shcharbin, D.; Pedziwiatr, E.; Nowacka, O.; Kumar, M.; Zaborski, M.; Ortega, P.; Javier de la Mata, F.; Gómez, R.; Muñoz-Fernandez, M.A.; Bryszewska, M. Carbosilane dendrimers NN8 and NN16 form a stable complex with siGAG1. Colloids Surf. B 2011, 83, 388-391. [CrossRef]

29. Szwed, A.; Fuentes-Paniagua, E.; Pedziwiatr-Werbicka, E.; Kurowska, J.; Gabryelak, T.; Gomez-Ramirez, R.; Moreno, S.; El Brahmi, N.; Milowska, K.; Katir, N.; et al. Synthesis, characterization and biological properties of new hybrid carbosilane-viologen-phosphorus dendrimers. RSC Adv. 2015, 5, 25942-25958.

30. Ziemba, B.; Halets, I.; Shcharbin, D.; Appelhans, D.; Voit, B.; Pieszyński, I.; Bryszewska, M.; Klajnert, B.; Klajnert-Maculewicz, B. Influence of fourth generation poly(propyleneimine) dendrimers on blood cells. J. Biomed. Mater. Res. Part A 2012, 100, 2870-2880. [CrossRef]

31. Klajnert, B.; Walach, W.; Bryszewska, M.; Dworak, A.; Shcharbin, D.; Klajnert-Maculewicz, B. Cytotoxicity, haematotoxicity and genotoxicity of high molecular mass arborescent polyoxyethylene polymers with polyglycidol-block-containing shells. Cell Boil. Int. 2006, 30, 248-252. [CrossRef] [PubMed]

32. Ziemba, B.; Matuszko, G.; Bryszewska, M.; Klajnert, B. Influence of Dendrimers on Red Blood Cells Cell. Mol. Biol. Lett. 2011, 17, 21-35. [CrossRef] [PubMed]

33. Shcharbin, D.; Shcharbina, N.; Milowska, K.; De La Mata, F.J.; Muñoz-Fernández, M.Á.; Mignani, S.; Gomez-Ramirez, R.; Majoral, J.-P.; Bryszewska, M. Interference of cationic polymeric nanoparticles with clinical chemistry tests-Clinical relevance. Int. J. Pharm. 2014, 473, 599-606. [CrossRef] [PubMed]

34. Sharma, A.K.; Gothwal, A.; Kesharwani, P.; Alsaab, H.; Iyer, A.K.; Gupta, U.; Gupta, D.U. Dendrimer nanoarchitectures for cancer diagnosis and anticancer drug delivery. Drug Discov. Today 2017, 22, 314-326. [CrossRef] [PubMed]

35. Lazniewska, J.; Milowska, K.; Katir, N.; El Kadib, A.; Bryszewska, M.; Majoral, J.-P.; Gabryelak, T. Viologen-phosphorus dendrimers exhibit minor toxicity against a murine neuroblastoma cell line. Cell. Mol. Boil. Lett. 2013, 18, 459-478. [CrossRef] 
36. Michlewska, S.; Ionov, M.; Maroto-Díaz, M.; Szwed, A.; Ihnatsyeu-Kachan, A.; Abashkin, V.; Dzmitruk, V.; Rogalska, A.; Denel, M.; Gapinska, M.; et al. Ruthenium dendrimers against acute promyelocytic leukemia: in vitro studies on HL-60 cells. Futur. Med. Chem. 2019. [CrossRef] [PubMed]

37. Maroto-Díaz, M.; Elie, B.T.; Gómez-Sal, P.; Pérez-Serrano, J.; Gómez, R.; Contel, M.; De La Mata, F.J. Synthesis and anticancer activity of carbosilane metallodendrimers based on arene ruthenium (II) complexes. Dalton Trans. 2016, 45, 7049-7066. [CrossRef]

38. Milowska, K.; Rybczyńska, A.; Mosiolek, J.; Durdyn, J.; Szewczyk, E.M.; Katir, N.; Brahmi, Y.; Majoral, J.-P.; Bousmina, M.; Bryszewska, M.; et al. Biological Activity of Mesoporous Dendrimer-Coated Titanium Dioxide: Insight on the Role of the Surface-Interface Composition and the Framework Crystallinity. ACS Appl. Mater. Interfaces 2015, 7, 199994-200003. [CrossRef]

39. Koceva-Chyła, A.; Matczak, K.; Hikisz, M.P.; Durka, M.K.; Kochel, M.K.; Süss-Fink, G.; Furrer, J.; Kowalski, K. Insights into the in vitro Anticancer Effects of Diruthenium-1. ChemMedChem 2016, 11, 2171-2187. [CrossRef]

40. Dickerson, M.; Sun, Y.; Howerton, B.; Glazer, E.C. Modifying Charge and Hydrophilicity of Simple Ru(II) Polypyridyl Complexes Radically Alters Biological Activities: Old Complexes, Surprising New Tricks. Inorg. Chem. 2014, 53, 10370-10377. [CrossRef]

41. Zhao, Z.; Luo, Z.; Wu, Q.; Zheng, W.; Feng, Y.; Chen, T. Mixed-ligand ruthenium polypyridyl complexes as apoptosis inducers in cancer cells, the cellular translocation and the important role of ROS-mediated signaling. Dalton Trans. 2014, 43, 17017-17028. [CrossRef] [PubMed]

42. Denora, N.; Laquintana, V.; Lopalco, A.; Iacobazzi, R.M.; Lopedota, A.; Cutrignelli, A.; Iacobellis, G.; Annese, C.; Cascione, M.; Leporatti, S.; et al. In vitro targeting and imaging the translocator protein TSPO 18-kDa through G(4)-PAMAM-FITC labeled dendrimer. J. Control. Release 2013, 172, 1111-1125. [CrossRef] [PubMed]

43. Michlewska, S.; Ionov, M.; Maroto-Diaz, M.; Szwed, A.; Ihnatsyeu-Kachan, A.; Loznikova, S.; Shcharbin, D.; Malý, M.; Ramírez, R.G.; De La Mata, F.J.; et al. Ruthenium dendrimers as carriers for anticancer siRNA. J. Inorg. Biochem. 2018, 181, 18-27. [CrossRef] [PubMed]

44. Huang, Y.-F.; Chattopadhyay, S.; Jen, Y.-J.; Peng, C.-Y.; Liu, T.-A.; Hsu, Y.-K.; Pan, C.-L.; Lo, H.-C.; Hsu, C.-H.; Chang, Y.-H.; et al. Improved broadband and quasi-omnidirectional anti-reflection properties with biomimetic silicon nanostructures. Nat. Nanotechnol. 2007, 2, 770-774. [CrossRef] [PubMed] 